\title{
Regulation of Corticotropin Receptor Number and Messenger RNA in Cultured Human Adrenocortical Cells by Corticotropin and Angiotensin II
}

\author{
Marie-Christine Lebrethon, Danielle Naville, Martine Begeot, and José M. Saez \\ Institut National de la Santé et Recherche Médicale U 307, Hôpital Debrousse, 69322 Lyon Cedex 05, France
}

\begin{abstract}
The regulation of ACTH receptor binding sites and mRNA by ACTH and angiotensin II (A-II) was studied using cultured human adrenal fasciculatareticularis cells (HAC). These cells expressed two major ACTH receptor transcripts of 1.8 and 3.4 $\mathrm{kb}$ and three minor ones of 4, 7, and $11 \mathrm{~kb}$. ACTH increased the levels of all these transcripts in a time- and dose-dependent manner. At a maximal concentration of $10^{-8} \mathrm{M}, \mathrm{ACTH}$ enhanced 21- and 4-fold the level of ACTH receptor mRNA and the number of receptors per cell, respectively. Pretreatment of HAC with A-II produced a dose-dependent enhancement of ACTH receptor mRNA that was associated with an increase of both ACTH receptor number and responsiveness to this hormone. The effects of A-II were completely blocked by an AT1 receptor subtype antagonist but not by an $\mathrm{AT} 2$ antagonist. The effects of ACTH together with A-II on ACTH receptor mRNA were greater than those induced by each hormone alone. These results show that $A C T H$ receptor number and $m R N A$ are positively regulated by the two main hormones (ACTH and A-II) which, in vivo, regulate adrenocortical functions. In addition, they also show that HAC are a target for A-II. Thus, regulation of ACTH receptors may be one mechanism by which ACTH and A-II regulate adrenocortical functions under both normal and pathological conditions. (J. Clin. Invest. 1994. 93:18281833.) Key words: adrenal fasciculata cells • angiotensin receptor subtype AT1 • steroidogenesis - ACTH receptor upregulation - hormone responsiveness
\end{abstract}

\section{Introduction}

In mammals, ACTH is the main hormone that regulates glucocorticoid secretion by the adrenal gland, whereas both ACTH and angiotensin II (A-II) ${ }^{1}$ regulate aldosterone secretion (1). Although detection and characterization of $\mathrm{ACTH}$ receptors have been difficult ( for review see reference 2), binding studies

Address correspondence to Dr. J. M. Saez, INSERM U 307, Hôpital Debrousse, 29 Rue Soeur Bouvier, 69322 Lyon Cedex 05, France.

Received for publication 31 March 1993 and in revised form 12 January 1994.

1. Abbreviations used in this paper: A-II, angiotensin II; F-12, Ham's nutrient mixture F-12; HAC, human adrenal fasciculata-reticularis cells.

J. Clin. Invest.

(c) The American Society for Clinical Investigation, Inc.

$0021-9738 / 94 / 04 / 1828 / 06 \$ 2.00$

Volume 93, April 1994, 1828-1833 using ACTH that has been labeled on Tyr-23 have demonstrated the presence of physiologically relevant receptors in adrenal cells of several species (3-8). The ACTH receptor gene has recently been cloned (9), and the predicted amino acid sequence has demonstrated that this receptor is one of the smallest of the seven transmembrane domain receptors identified to date, has a theoretical molecular mass of $\sim 34 \mathrm{kD}$, and contains two putative glycosylation sites. By cross-linking experiments, the molecular mass of ACTH receptor has been reported to be $40 \mathrm{kD}(10)$.

Contradictory results have been reported concerning the regulation of ACTH receptor number by ACTH itself: a positive effect has been reported in some studies $(7,8,11)$, whereas a lack of effect was reported in others $(12,13)$. Until now, no study has been reported concerning the regulation of human ACTH receptors. Because the regulation of ACTH receptors might be an important mechanism involved in the responsiveness of adrenocortical cells, we report in the present studies on the regulation of both ACTH receptor number and mRNA in human adrenal fasciculata-reticularis cells by ACTH and A-II, and demonstrate that both hormones have a positive effect on both parameters. In addition, we demonstrate that these cells are target for A-II.

\section{Methods}

Synthetic adrenocorticotropin ( ACTH-1-24) was purchased from Ciba (Rueil-Malmaison, France); synthetic angiotensin-II (A-II) from Bachem (Bubendorf, Switzerland); ${ }^{125}$ I-labeled human (Tyr23) ACTH(1-39) (specific activity $=74 \mathrm{TBq} / \mathrm{mmol}$ ) from Amersham (Les Ulis, France); insulin, transferrin, and bacitracin from Sigma Immunochemicals (Saint Louis, MO), BSA from Boehringer Mannheim (Meylan, France); nystatin from Gibco (Paris, France); and penicillin/streptomycin, fetal calf serum, and Dulbecco's modified Eagle's medium/ Ham's nutrient mixture F-12 (F-12) (1:1) from JBio (Villejust, France). All other reagents came from Sigma Immunochemicals. Specific antagonist DuP-753 (or losartan) was obtained from Du Pont Merck (Wilmington, DE), and CGP 42112A was a gift of Dr. de Gasparo (Ciba-Geigy, Basel, Switzerland).

Human adrenal cell isolation and culture. Human adult adrenals were obtained after organs were removed from brain-dead patients for transplantation, with the approval of the ethical committee of the Hospices Civils de Lyon. After having removed the major part of the medulla, the zona fasciculatareticularis was separated from the capsula and used for cell preparation. Cells were dispersed by two collagenase/ DNAse digestions $(1 \mathrm{mg} / \mathrm{ml}$ per $0.1 \mathrm{mg} / \mathrm{ml})$ in DMEM/F-12 medium, supplemented with $\mathrm{NaHCO}_{3}(14 \mathrm{mM})$ and Hepes $(10 \mathrm{mM})$ containing gentamycin $(20 \mu \mathrm{g} / \mathrm{ml})$, penicillin $(100 \mathrm{U} / \mathrm{ml})$, streptomy$\operatorname{cin}(0.1 \mathrm{mg} / \mathrm{ml})$, and nystatin $(100 \mathrm{U} / \mathrm{ml})$. Cells were then seeded in monolayer cultures in the same medium containing $10 \%$ fetal serum plus insulin $(10 \mu \mathrm{g} / \mathrm{ml})$, transferrin $(10 \mu \mathrm{g} / \mathrm{ml})$, and vitamin $\mathrm{C}\left(10^{-4}\right.$ $M)$. After $24 \mathrm{~h}$, the medium was changed to the same medium without 
serum. Treatments were conducted in this medium starting on day 2 or 3 of culture.

Receptor binding assays. At the end of the experimental period, the medium was removed and the cells were washed twice with ice-cold $0.9 \% \mathrm{NaCl}$, once with ice-cold acidic glycine buffer ( $50 \mathrm{mM}$ glycine/ $100 \mathrm{mM} \mathrm{NaCl}, \mathrm{pH} 3$ ) for $4-5 \mathrm{~min}$ at $4^{\circ} \mathrm{C}$, and twice with $0.9 \% \mathrm{NaCl}$ to remove the membrane-bound ligand. Then the cells were incubated for $1 \mathrm{~h}$ at $20^{\circ} \mathrm{C}$ with $\sim 1.8 \times 10^{5} \mathrm{cpm}$ of $\left[{ }^{125} \mathrm{I}\right] \mathrm{ACTH}$ in F-12/DME containing $0.5 \%$ bovine serum albumin and $0.1 \%$ bacitracin. At the end of the incubation, the medium was removed, and the cells were washed three times with $0.9 \% \mathrm{NaCl}$ and then dissolved in $0.5 \mathrm{M}$ $\mathrm{NaOH} / 0.4 \%$ sodium deoxycholate. The radioactivity was measured in a $\gamma$ counter with $75 \%$ efficiency. Nonspecific binding was determined by the addition of $10^{-6} \mathrm{M}$ unlabeled ACTH.

RNA extraction and Northern blot analysis. Total RNA was isolated from cells by the method of Chomczynski and Sacchi (14). Samples were separated by electrophoresis through a $1.0 \%$ agarose gel containing $8 \%$ formaldehyde. RNA was then transferred to a membrane (Hybond-N; Amersham). Prehybridization was performed in SSC $(5 \times)$, pH 7.0, containing $50 \%$ formamide, $1 \times \mathrm{PE}(5 \times \mathrm{PE}=250 \mathrm{mM}$ Tris- $\mathrm{HCl}, \mathrm{pH} 7.5,0.5 \%$ sodium pyrophosphate, $5 \%$ SDS, $1 \%$ polyvinylpyrrolidone, $1 \%$ Ficoll, $25 \mathrm{mM}$ EDTA, and $1 \%$ BSA), and $150 \mu \mathrm{g} / \mathrm{ml}$ salmon sperm DNA at $42^{\circ} \mathrm{C}$ for $4 \mathrm{~h}$. Hybridization was performed in the same buffer at $42^{\circ} \mathrm{C}$ for $24 \mathrm{~h}$, using a 955 -bp fragment of the human ACTH receptor as probe $\left(10^{6} \mathrm{dpm} / \mathrm{ml}\right)$. This probe was prepared by PCR amplification using human genomic DNA as template. Primers were designed from the ACTH receptor published sequence (9) (considering the A of the translation initiation codon ATG as position +1 , these two oligonucleotides were named: -22S 5'-GCCTTAACCACAAGCAGGAG-3' and +933 AS 5'-CGTTATTCCCATGGATTCTA$\left.3^{\prime}\right)$, and the resulting fragment ( $955 \mathrm{bp}$ ) contained the whole coding sequence of the gene. This PCR fragment was then subcloned into SmaI-cleaved pTZ18 (Pharmacia, Saint-Quentin-en-Yvelines, France). The probe was recovered after cutting with EcoRI and BamHI restriction enzymes. Labeling of this probe in the presence of $\left[\alpha^{32} \mathrm{P}\right] \mathrm{dCTP}$ was performed (Multiprime DNA labeling system; Amersham). The blots were washed two times in a $2 \times$ SSC buffer containing $0.1 \%$ SDS at room temperature for $15 \mathrm{~min}$; one time in a 0.2 $\times$ SSC containing $0.1 \%$ SDS at room temperature for $30 \mathrm{~min}$ and finally $10 \mathrm{~min}$ at $55^{\circ} \mathrm{C}$ in the same buffer. The blots were exposed to $\mathrm{x}$-ray film at $-70^{\circ} \mathrm{C}$ with two intensifying screens. The relative intensity of hybridization signals was quantified by scanning densitometry (Preference HIT; Sebia, Paris, France). Equal loading of RNA samples was confirmed by photographing the ethidium bromide-stained membranes with Polaroid type 55 films and scanning the 28S RNA images on the photograph negatives.

Other methods. At the end of each experimental protocol, the cells were washed and incubated in fresh medium in the presence of $10^{-8} \mathrm{M}$ ACTH. One aliquot of the medium was removed after $2 \mathrm{~h}$ for steroid measurement. Samples were frozen until the specific radioimmunoassays were performed (15).

\section{Results}

Northern blot analysis of human adrenal fasciculata-reticularis cells (HAC) mRNA under moderate stringency conditions revealed predominant transcripts at 1.8 and $3.4 \mathrm{~kb}$, as well as less intense bands of 4, 7, and $11 \mathrm{~kb}$ (Fig. 1). Similar transcripts were observed using RNA extracted from whole human adrenal (data not shown). All transcripts were increased by a 4-d treatment with either ACTH $\left(10^{-8} \mathrm{M}\right)$ or A-II $\left(10^{-7} \mathrm{M}\right)$, but the effect of ACTH was greater than that of A-II, but lower than that produced by the addition of both hormones (Fig. 1). The effect of A-II was probably caused by a direct action of the peptide on fasciculata-reticularis cells, since the contamination by glomerulosa cells was very small $(<10 \%)$.

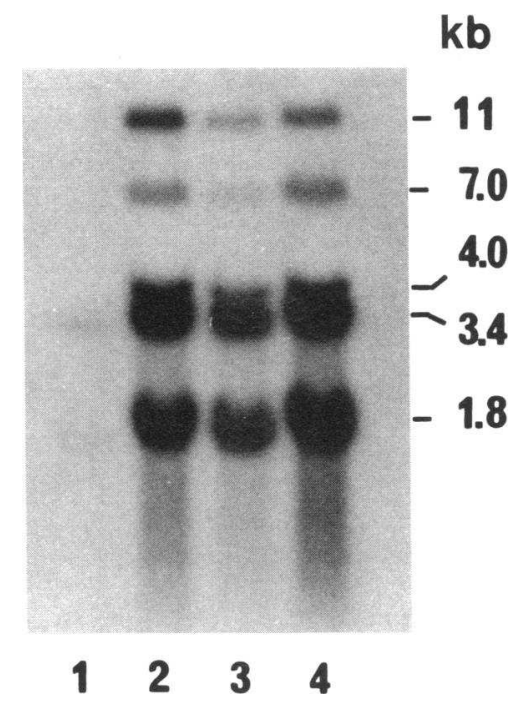

Figure 1. Effect of ACTH, A-II, and ACTH + A-II on HAC ACTH receptors mRNAs. From the second day of culture, cells were incubated for 72 $h$ in fresh medium with or without $10^{-8} \mathrm{M}$ ACTH, $10^{-7} \mathrm{M}$ A-II or $10^{-8} \mathrm{M} \mathrm{ACTH}+10^{-7}$ $\mathrm{M}$ AII. At the end of the incubation period, human ACTH receptor mRNAs were analyzed as described in Methods. Northern blot analysis revealed two major transcripts of 1.8 and $3.4 \mathrm{~kb}$ and three minor transcripts of 4,7 , and

$11 \mathrm{~kb}$. Lane 1 , control, lane $2,10^{-8} \mathrm{M}$ ACTH; lane $3,10^{-7} \mathrm{M}$ AII; lane $4,10^{-8} \mathrm{M} \mathrm{ACTH}+10^{-7} \mathrm{M}$ A-II.

The stimulatory effects of both ACTH and A-II on ACTH receptor mRNA were dose dependent. Maximum effect was observed at $10^{-8} \mathrm{M}$ ACTH (Fig. $2 A$ ) with an $\mathrm{ED}_{50} \sim 10^{-9} \mathrm{M}$. Treatment of cells with $10^{-7} \mathrm{M}$ (data not shown) produced similar effects than those induced by $10^{-8} \mathrm{M}$ ACTH. At maximal concentrations, ACTH induced a 21 -fold increase of its own receptor mRNA. The concentrations of the hormone required to induce a half-maximal and a maximal effect on ACTH receptor mRNA were about one order of magnitude higher than those required to stimulate cortisol secretion (data not shown). Such discrepancy has also been observed in bovine adrenal cells concerning the effects of ACTH on cortisol output and on the number of its own receptors (7). This effect is probably caused by the fact that the concentrations of ACTH that cause half-maximal cAMP production are also about one order of magnitude higher than those required to stimulate cortisol secretion (6). The maximal effect of A-II (17-fold increase) was observed at $10^{-7} \mathrm{M}$ (Fig. $2 \mathrm{~B}$ ). Treatment of cells with $10^{-6} \mathrm{M}$ (data not shown) produced similar effects than $10^{-7} \mathrm{M}$. In the case of A-II, there was a good agreement between the concentrations of the hormone required to induce ACTH receptor mRNA and those required to induce cortisol secretion (data not shown). The effects of A-II were inhibited by $8 \times 10^{-5} \mathrm{M}$ losartan, an antagonist of the AT1 receptor subtype, but not by CGP $42112 \mathrm{~A}$, an antagonist of the AT2 receptor subtype (Table I).

Since the effects of ACTH and A-II on adrenal cells are mediated through cAMP and phosphoinositide pathways, respectively, we investigated whether their effects on ACTH receptor mRNA were additive. Fig. 1 shows that the levels of all ACTH receptor transcripts were higher in cells treated with both hormones than in cells treated with each hormone alone at maximal concentration. Quantification of different transcripts by scanning densitometry reveals that the effects were additive (Table I).

The stimulatory effects of ACTH and A-II on ACTH receptor mRNAs could be caused by transcriptional or posttranscriptional modifications. Since the number of cells obtained 


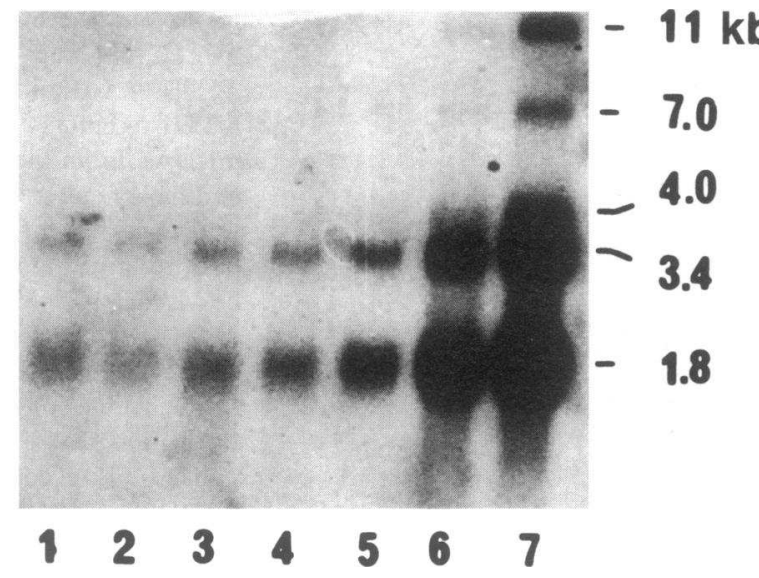

B

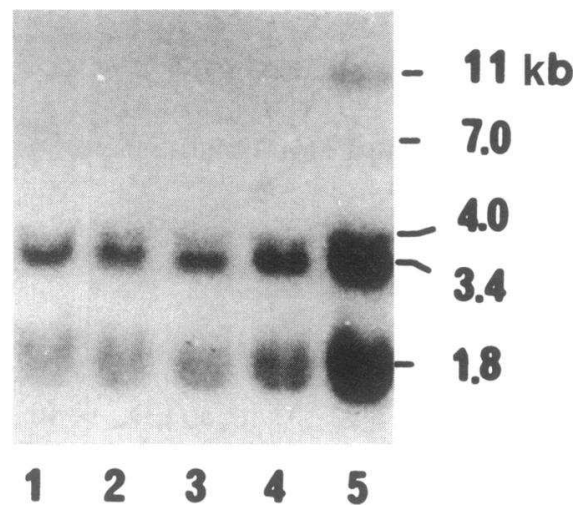

Figure 2. Dose response effects of ACTH and A-II on HAC ACTH receptor mRNAs. From the second day of culture, cells were incubated for $72 \mathrm{~h}$ in fresh medium containing increasing concentrations of ACTH or A-II. At the end of the incubation, human ACTH receptor mRNAs were analyzed as outlined in Methods. $(A)$ Representative Northern blot for increasing concentrations of ACTH (lane 1 , control; lane $2,10^{-13}$; lane $3,10^{-12}$, lane $4,10^{-11}$; lane $5,10^{-10}$; lane $6,10^{-9}$, lane $\left.7,10^{-8} \mathrm{M}\right)$. (B) representative Northern-blot for different concentrations of A-II (lane 1 , control; lane 2, $10^{-10}$; lane 3, $10^{-9}$; lane $4,10^{-8}$; lane $\left.5,10^{-7} \mathrm{M}\right)$. for each adrenal ( $3-4 \times 10^{7}$ cells ) was insufficient to performed run-on experiments under the three conditions, control, $\mathrm{ACTH}$, and A-II, we have investigated the half-life of the ACTH receptor mRNA. Cells were incubated for $24 \mathrm{~h}$ in the absence or presence of ACTH $\left(10^{-8} \mathrm{M}\right)$ or A-II $\left(10^{-7} \mathrm{M}\right)$, and then actinomycin $\mathrm{D}(10 \mu \mathrm{g} / \mathrm{ml})$ was added, and the levels of ACTH receptor mRNA levels (1.8- and 3.4-kb transcripts) were evaluated at $3,6,9$, and $12 \mathrm{~h}$. The results of three different experiments shown in Fig. 3, demonstrated that the half-life of ACTH receptor mRNA in control, as well as A-II- and ACTHtreated cells was $6 \pm 0.11,7.75 \pm 0.4$, and $12 \pm 1.58 \mathrm{~h}$, respectively.

Next, we investigated the time course effects of both hormones alone or together on ACTH receptor mRNA. Fig. 4 shows that $(a)$ the stimulatory effects of both hormones could be seen within $12 \mathrm{~h} ;(b)$ at any time the effects of A-II were less than those of $\mathrm{ACTH}$, which in turn were less than those of both hormones together; and $(c)$ the maximum effect was observed between 48 and $72 \mathrm{~h}$.

Since the effects of both hormones on ACTH receptor mRNA were very rapid (Fig. 4), we wondered if these effects reflect "early response" or "late response." Cells were incubated for $12 \mathrm{~h}$ in the absence or presence of ACTH $\left(10^{-8} \mathrm{M}\right)$ or A-II $\left(10^{-7} \mathrm{M}\right)$ without or with cycloheximide $(5 \mu \mathrm{g} / \mathrm{ml})$, a concentration which blocks $>95 \%$ protein synthesis (data not shown), and the ACTH receptor mRNA levels were evaluated at the end of the experiment. The results in Table II show that the antibiotic reduced the ACTH receptor mRNA levels in control cells by $60 \%$, blocked almost completely the stimulatory effects of ACTH, and reduced the effects of A-II by $75 \%$.

To determine if the increase of ACTH receptor mRNA was associated with an increase of the number of ACTH binding sites, cells were treated for $72 \mathrm{~h}$ with ACTH. After a glycine wash to remove the membrane bound ligands, ACTH receptor number was measured in control and ACTH-pretreated cells. Scatchard analysis of the binding data (Fig. 5) revealed that control human adrenocortical cells contain two types of binding sites, one of high affinity $\left(K_{d}=5.7 \pm 2.5 \times 10^{-10} \mathrm{M}, n=3\right)$ and low capacity $(850 \pm 50$ sites/cell $)$, the second of low affin-

Table I. Effects of ACTH, A-II, or both on ACTH Receptor Number and ACTH Responsiveness in Human Adrenal Fasciculata-Reticularis Cells

\begin{tabular}{|c|c|c|c|c|}
\hline \multirow[b]{2}{*}{ Pretreatment } & \multirow[b]{2}{*}{ Cortisol } & \multicolumn{2}{|c|}{$\begin{array}{c}\text { ACTH receptor } \\
\text { (-fold stimulation over control) } \\
\end{array}$} & \multirow{2}{*}{$\frac{\text { ACTH response }}{\text { Cortisol }}$} \\
\hline & & mRNA & Binding & \\
\hline & $n g / 24 h$ & & & $n g / 2 h$ \\
\hline Control & $713 \pm 48^{*}$ & $1^{*}$ & $1^{*}$ & $400 \pm 31^{*}$ \\
\hline ACTH $10^{-8} \mathrm{M}$ & $39,180 \pm 5,100^{\ddagger}$ & $21 \pm 2.5^{\ddagger}$ & $4.8 \pm 0.4^{\ddagger}$ & $5,044 \pm 290^{\ddagger}$ \\
\hline A-II $10^{-7} \mathrm{M}$ & $6,643 \pm 74^{\S}$ & $17 \pm 4^{\ddagger}$ & $3.5 \pm 0.3^{\ddagger}$ & $1,739 \pm 39^{\S}$ \\
\hline $\mathrm{ACTH}+\mathrm{A}-\mathrm{II}$ & $37,990 \pm 2,101^{\ddagger}$ & $46 \pm 6^{8}$ & $5.7 \pm 0.6^{\ddagger}$ & $3,375 \pm 290^{\ddagger}$ \\
\hline A-II + losartan $10^{-5} \mathrm{M}$ & $1,180 \pm 50^{*}$ & $1.2^{\| \prime}$ & - & $500 \pm 39^{*}$ \\
\hline A-II + CGP 42112A & $7,400 \pm 600^{8}$ & $17.7^{11}$ & - & $1,538 \pm 25^{\S}$ \\
\hline
\end{tabular}

Different superscripts in the same column indicate a significant difference $(P<0.05)$. "A single experiment. Human adrenal fasciculata-reticularis cells were treated for $3 \mathrm{~d}$ with the indicated compounds. The cortisol production during the last $24 \mathrm{~h}$ of culture was measured. Then the ACTH receptor number and mRNA, as well as the acute $(2 \mathrm{~h})$ cortisol production in response to $10^{-8} \mathrm{M}$ ACTH were measured. The results are given as the mean $\pm \mathrm{SE}$ of two to six different experiments. 


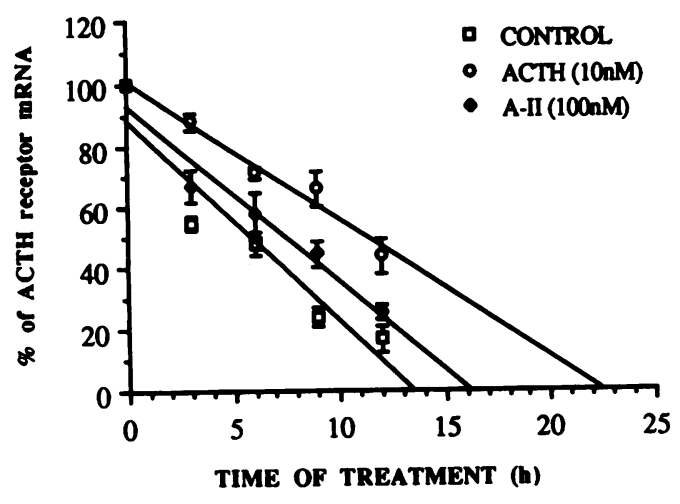

Figure 3. Effects of ACTH and A-II on ACTH receptor mRNA halflife. Beginning on the second day of culture, cells were incubated for $24 \mathrm{~h}$ in fresh medium with or without $10^{-8} \mathrm{M} \mathrm{ACTH} \mathrm{or} 10^{-7} \mathrm{M} \mathrm{A-II}$, and then actinomycin $\mathrm{D}(10 \mu \mathrm{g} / \mathrm{ml})$ was added (time 0$)$. At $0,3,6$, and $12 \mathrm{~h}$, human ACTH receptor mRNAs were analyzed as described in Methods. The results are given as the mean of three different experiments.

ity $\left(K_{\mathrm{d}}=5 \times 10^{-8} \mathrm{M}\right)$ and high capacity $(20,000$ sites $/$ cell $)$. Two types of ACTH binding sites have also been reported for rat (5), bovine (7), ovine (8), and chicken (4) adrenal cells. For most of these models, the physiological significance of the low affinity binding sites is unknown, since it cannot be related to any physiological responses of adrenal cells, and this seems to be the case for HAC.

Pretreatment with ACTH produced a three- to fourfold increase in the number of the high affinity sites, without any significant effect on the $K_{\mathrm{d}}$ (Fig. 5). The effects of ACTH on the low affinity binding sites (affinity and number) were not significant. A-II pretreatment also increased the number of ACTH binding sites, but its effects were less than those produced by ACTH, which in turn were less than those produced by the two hormones added together (Table I). It must be pointed out that the effects of both hormones, either alone or together, on ACTH receptor mRNA levels were four to five times higher than their effects on $\mathrm{ACTH}$ receptor number. One

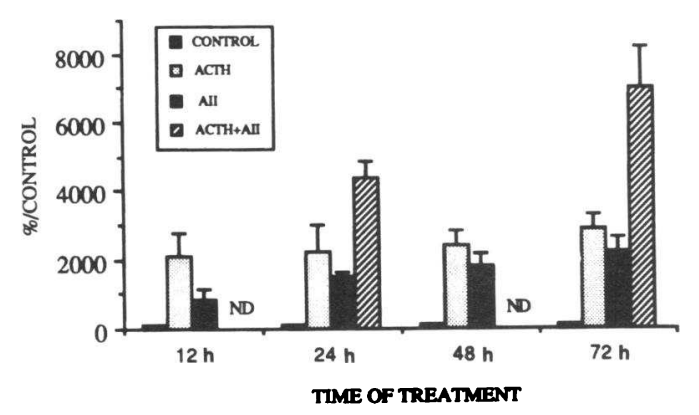

Figure 4. Time course of ACTH, A-II, and ACTH + A-II effects on HAC ACTH receptor mRNAs. On the second day of culture, cells were incubated in fresh medium with or without $10^{-8} \mathrm{M} \mathrm{ACTH}, 10^{-7}$ $\mathrm{M} \mathrm{A}-\mathrm{II}$, or $10^{-8} \mathrm{M} \mathrm{ACTH}+10^{-7} \mathrm{M}$ A-II for various periods of time, and the human ACTH receptor mRNAs were analyzed as outlined in Methods. The results of the sum of the two major transcripts ( 1.8 and $3.4 \mathrm{~kb}$ ) are expressed as the percentage of increase in treated cells over the control cells and are the mean \pm SEM of three Northern blots. ND, not determined.
Table II. Effects of Protein Synthesis Inhibitor on ACTH Receptor $m R N A$ Levels

\begin{tabular}{lcr}
\hline & \multicolumn{2}{c}{ ACTH receptor mRNA (\% of control) } \\
\cline { 2 - 3 } \multicolumn{1}{c}{ Treatment } & $\begin{array}{c}\text { Without } \\
\text { cycloheximide }\end{array}$ & $\begin{array}{c}\text { With } \\
\text { cycloheximide }\end{array}$ \\
\hline Control & 100 & $39 \pm 11^{\ddagger}$ \\
ACTH $10^{-8} \mathrm{M}$ & $1,714 \pm 623^{*}$ & $110 \pm 55^{\ddagger}$ \\
A-II $10^{-7} \mathrm{M}$ & $1,587 \pm 438^{*}$ & $575 \pm 323^{\ddagger}$ \\
\hline
\end{tabular}

${ }^{*} P<0.01$ compare to control of the same column. ${ }^{\ddagger} P<0.01 \mathrm{com}-$ pare to the corresponding values - cycloheximide.

Human adrenal fasciculata-reticularis cells were treated for $12 \mathrm{~h}$ in the absence or presence of ACTH $10^{-8} \mathrm{M}$ or A-II $10^{-7} \mathrm{M}$ without or with cycloheximide $(5 \mu \mathrm{g} / \mathrm{ml})$. At the end of treatment, ACTH receptor mRNA levels were evaluated. The results expressed as percent of control are the mean \pm SEM of three different experiments.

possible explanation for this discrepancy might be an increase in the rate of internalization-degradation of the ACTH receptor in treated cells, similar to that observed for A-II receptors in bovine adrenocortical cells (15).

The stimulatory effect of ACTH and A-II on ACTH receptors was associated with an enhanced steroidogenic response to further ACTH stimulation as compared to control cells ( Table I). Again, the effects of ACTH were significantly greater than those produced by A-II. However, the responsiveness of cells pretreated with ACTH plus A-II was lower than that of ACTHpretreated cells. The reason for this is unknown, but could be related to some inhibition by A-II of the positive effects of ACTH on the expression of the gene encoding for several steroidogenic enzymes. The data of Table I show that A-II was able to stimulate cortisol production by human adrenal fasciculata cells, confirming that these cells are a target for A-II.

\section{Discussion}

ACTH and A-II are the two main hormones that control adrenocortical functions under physiological conditions. Therefore, determining the mechanism that regulates the number of

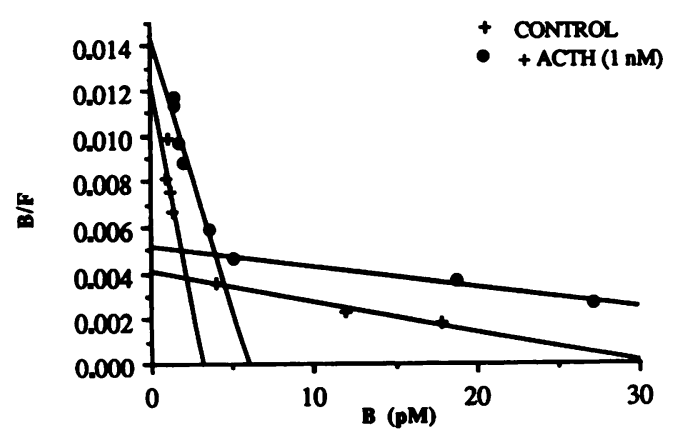

Figure 5. Scatchard analysis of the inhibition of binding of ${ }^{125}$ I-labeled human $\left(\mathrm{Tyr}^{23}\right.$ ) ACTH to human adrenal cells by increasing concentrations of unlabeled ACTH. Cells were incubated for $72 \mathrm{~h}$ in the absence $(+)$ or presence $(\bullet)$ of $10^{-9} \mathrm{M} \mathrm{ACTH}$. Then the medium was removed, and the cells were washed with an acidic buffer and incubated with ${ }^{125} \mathrm{I}-\mathrm{ACTH}$ in the presence of increasing concentrations of cold ACTH. $B$, bound ligand; $F$, free ligand. 
receptors for these two hormones on adrenocortical cells should be of primary importance. In contrast with the loss of receptors and the desensitization of target cells induced by many hormones (16), our results show clearly that ACTH produces an increase of its own receptors on human adrenal fasciculata-reticularis cells. These results are similar to those previously reported, for both bovine (7) and ovine (8) adrenocortical cells, where ACTH also increases its own receptor number. In these studies, however, no information was given concerning the levels of ACTH receptor mRNA, which had not yet been cloned.

The present results show that HAC contain several ACTH receptor transcripts, two major ones of 1.8 and $3.4 \mathrm{~kb}$, and three minor ones of 4,7 , and $11 \mathrm{~kb}$. In contrast, a single transcript of $4 \mathrm{~kb}$ has been found in Rhesus monkey adrenal (9, 17), and two mRNAs of 3.6 and $4.2 \mathrm{~kb}$ have been observed in bovine adrenocortical cells (Penhoat, A., and J. M. Saez, unpublished observation). Since the ACTH receptor gene contains a single exon in the coding region (9) and the probe we used contains the complete coding sequence, the presence of several transcripts might result from several initiation transcription sites and/or several polyadenylation sites. Interestingly, this different processing of ACTH receptor mRNA appears to be different among species.

ACTH produced in a dose- and time-dependent manner an increase of all ACTH receptor transcripts. At maximal concentration of the hormone, there was a 20 -fold increase of ACTH receptor mRNA, but only a twofold increase of it half-life. Therefore, it appears that ACTH enhances the accumulation of ACTH receptor mRNA mainly by increasing the rate of transcription. Moreover, both the constitutive and the ACTH-stimulated expression of ACTH receptor required de novo protein synthesis.

The classical concept of the lack of effect of A-II on the glucocorticoid secretion in human (1) was challenged by the present results showing that A-II stimulated cortisol production by cultured human fasciculata-reticularis cells. Moreover, these cells contain AT1 receptor subtype and express AT1 receptor mRNA, and both receptor number and $\mathrm{mRNA}$ are negatively regulated by A-II (18). Further evidence indicating that HAC are a target for A-II was given by the fact that the hormone increases the ACTH receptor mRNA levels in a dose-dependent manner, and that these effects are mediated mainly via transcriptional mechanisms. The possibility that these effects of A-II could be caused by the small contamination of our cell preparation with glomerulosa cells is unlikely. First, the aldosterone production after stimulation with A-II or ACTH was very low when compared to cortisol production (data not shown). Second, pretreatment with A-II not only significantly increased cortisol production, but also enhanced the steroidogenic response to further stimulation with ACTH, indicating that A-II was acting on fasciculata cells. In all species studied, including human, ACTH is able to stimulate the steroidogenesis of both glomerulosa and fasciculata cells (19), suggesting that both cell types contain ACTH receptors. In the rat, the number of ACTH receptors on glomerulosa cells is even higher than on fasciculata cells (5). Therefore, the higher ACTH receptor mRNA content observed after ACTH plus A-II treatment, compared to cells treated with each hormone alone is in favor of two different mechanisms regulating ACTH receptor mRNA levels, rather than the stimulation by each hormone of two different cell types.
In conclusion, the present results show for the first time that human adrenal fasciculata-reticularis cells contain high affinity ACTH binding sites, and that both binding sites and ACTH receptor mRNA are positively regulated by both ACTH and A-II. In addition, they also show that these cells are target for A-II. These results suggest that the enhanced glucocorticoid secretion observed in the human after repeated $(20)$ or longterm (21) treatment with ACTH, as well as in patients with Cushing's disease or with ectopic ACTH secretion (1), is probably not only caused by the positive trophic effect of ACTH on the expression of the gene encoding the enzymes of the steroidogenic pathway (22), but also to the positive effects of the hormone on its own receptors. The direct stimulatory effect of A-II on cortisol secretion by the fasciculata-reticularis cells and its trophic effect on ACTH receptor number and on ACTH responsiveness can explain why, under some clinical conditions (e.g., congenital adrenal hyperplasia with salt loss), normalization of fasciculata-reticularis cell functions (plasma levels of $17 \alpha$-hydroxyprogesterone) requires not only the suppression of ACTH plasma levels, but also the normalization of the renin-angiotensin system (23).

\section{Acknowledgments}

This work was supported in part by an Institut National de la Santé et Recherche Médicale-Merck, Sharp \& Dohme grant. The authors thank Drs. R. D. Smith and C. Sweet for providing DUP 753 and PD-123177, and Dr. M. De Gasparo for providing CGP 42112A. We thank the surgeons and the staff of the Bureau de Coordination Locale de Transplantation des Hospices Civils de Lyon for providing us with human adrenal glands. We also thank Dr. A. Clark for critical reading of the manuscript and J. Bois for secretarial help.

M.-C. Lebrethon is the recipient of a fellowship from la Fondation pour la Recherche Médicale Française.

\section{References}

1. Baxter, J. D., and J. B. Tyrrel. 1986. The Adrenal Cortex. In Endocrinology and Metabolism 2nd ed. P. Felig, J. D. Baxter, A. E. Broadus, and L. A. Frohman, editors. McGraw-Hill Inc., New York. pp. 511-692.

2. Ramachandran, J. 1986. Interaction of corticotropin with adrenocortical cells receptors. In Biochemical Action of Hormones. G. Litwack, editor. Academic Press, New York. pp. 167-190.

3. Buckley, D. I., and J. Ramachandran. 1981. Characterization of corticotropin receptors on adrenocortical cells. Proc. Natl. Acad. Sci. USA. 78:7431-7435.

4. Carsia, R. V., and H. Weber. 1988. Protein malnutrition in the domestic fowl induces alterations in adrenocortical cell adrenocorticotropin receptors. Endocrinology. 122:681-688.

5. Gallo-Payet, N., and E. Escher. 1985. Adrenocorticotropin receptors in rat adrenal glomerulosa cells. Endocrinology. 117:38-46.

6. Catalano, R. B., L. Stuve, and J. Ramachandran. 1986. Characterization of corticotropin receptors in human adrenocortical cells. J. Clin. Endocrinol. \& Metab. 62:300-304.

7. Penhoat, A., C. Jaillard, and J. M. Saez. 1989. Corticotropin positively regulates its own receptors and cAMP response in cultured bovine adrenal cells. Proc. Natl. Acad. Sci. USA. 86:4978-4981.

8. Rainey, W. E., I. Viard, and J. M. Saez. 1989. Transforming growth factor B treatment decreases ACTH receptors on ovine adrenocortical cells. J. Biol. Chem. 264:21474-21477.

9. Mountjoy, K. G., L. S. Robbins, M. T. Mortrud, and R. D. Cone. 1992. The cloning of a family of genes that encode the melanocontin receptors. Science (Wash. DC). 257:1248-1251.

10. Penhoat, A., C. Jaillard, and J. M. Saez. 1993. Identification and characterization of corticotropin receptors in bovine and human adrenals. J. Steroid Biochem. Mol. Biol. 44:21-27.

11. Durand, P., and A. Locatelli. 1980. Up regulation of corticotropin receptors by ACTH 1-24 in normal and hypophysectomized rabbits. Biochem. Biophys. Res. Commun. 90:447-450.

12. Morera, A. M., A. M. Cathiard, and J. M. Saez. 1978. ACTH induced refractoriness in cultured adrenal cell line Y1. Biochem. Biophys. Res. Commun. 83:1553-1560. 
13. Sheela Rani, C. S., G. Keni, and J. Ramachandran. 1983. Studies on corticotropin induced desensitization of normal rat adrenocortical cells. Endocrinology. 112:315-320.

14. Chomczynski, P., and P. Sacchi. 1987. Single step method of RNA isolation by acid guanidium thiocyanate phenol chloroform extraction. Anal. Biochem. 162:156-159.

15. Penhoat, A., C. Jaillard, A. Crozat, and J. M. Saez. 1988. Regulation of angiotensin-II receptors and steroidogenic responsiveness in cultured bovine fasciculata and glomerulosa adrenal cells. Eur. J. Biochem. 172:247-254.

16. Catt, K. J., J. P. Harwood, G. Aguilera, and M. L. Dufau. 1979. Hormonal regulation of peptide receptors and target cell responses. Nature (Lond.) 280:109-116.

17. Cone, R. D., and K. G. Mountjoy. 1992. Cloning and functional characterization of the human adrenocorticotropin receptor. In Cellular and Molecula Biology of the Adrenal Cortex. J. M. Saez, A. C. Brownie, A. Capponi, E. M. Chambaz, and F. Mantero, editors. Colloque INSERM/John Libbey Eurotext, Paris. 222:27-40.

18. Naville, D., M. C. Lebrethon, A. Y. Kermabon, E. Rouen, R. Benarous, and J. M. Saez. 1993. Characterization and regulation of the angiotensin-II type receptor (Binding and mRNA) in human adrenal fasciculata reticularis cells. FEBS (Fed. Eur. Biochem. Soc.) Lett. 321:184-188.

19. Quinn, S. J., and G. H. Williams. 1988. Regulation of aldosterone secretion. Annu. Rev. Physiol. 50:409-426.

20. Kolanowski, J., W. Esselinckx, C. Nagant de Deux Chaisnes, and J. Crabbe. 1977. Adrenocortical response up on repeated stimulation with corticotrophin in patients la endogenesis corticotrophin secretion. Acta Endocrinol. (Copenhagen). 85:595-607.

21. Oelkers, W. 1985. Prolonged ACTH infusion suppresses aldosterone secretion in spite of high renin activity. Acta Endocrinol. (Copenhagen). 108:9197.

22. Simpson, E. R., and M. R. Waterman. 1988. Regulation of the synthesis of steroidogenic enzymes in adrenal cortical cells by ACTH. Annu. Rev. Physiol. 50:427-440.

23. New, M. I., P. C. White, S. Pang, B. Dupont, and P. W. Speiser. 1989. The adrenal hyperplasia. In The Metabolic Basis of Inherited Diseases. 6th ed. C. Scriver, A. Beaudet, W. Sly, and D. Valle, editors. McGraw-Hill Inc., New York. 1881-1917. 